\title{
Study of Innovative Module on Maker Concept in Brand Image Planning
}

\author{
Yang Li \\ The Department of Art \\ Zhuhai College of Jilin University \\ Zhuhai, China
}

\begin{abstract}
Combining with the nature of the courses planned by the brand image and the demand of the society for the application talents of advertising, this article incorporates the concept of maker into the course of brand image planning, innovates the teaching modules, improves the teaching system and the design efficiency. It has provided new method and practical reference for higher education to cultivate innovative entrepreneurial application-oriented talents.
\end{abstract}

Keywords—maker concept; brand image planning; module; project teaching

\section{INTRODUCTION}

"Brand image planning" is a practical, highly-skilled course. And the students of advertising major must master this professional course. In accordance with the specific requirements of the curriculum settings of colleges and universities and the construction of excellent courses, the university should boldly and continuously have the reform and practice. Also, the colleges and universities should make the innovation and keep the exploration. Gradually, it has formed a course teaching system with the characteristics of the art department. At present, this course is at a relatively advanced level among the similar institutions in the province in terms of the organization of teaching contents, the conditions of teaching practice, the disposition of teaching materials, the modernization of teaching methods and the teaching staff.

The new generation of information technologies, represented by mobile Internet, cloud computing, Internet of Things and big data, is driving profound changes in all fields of society. The cross-border integration of the Internet and various industries is bound to lead to new economic pattern. For example, the recent concept of "Intemet + " is new product in large environment. In fact, in addition to the upgrading of the industry's shape, the Internet and many emerg ing technologies such as 3D technology (including 3D display technology, 3D virtual reality technology and 3D printing technology), the development of software / hardware, etc., also have substantive impact on individual innovation. And it has greatly promoted the development of global maker movement.

Foreign maker culture has been developed perfectly. The maker space derived from maker culture has become common practice. We could take the United States as the example. In colleges and universities, it has established complete system of maker, such as more than 10 courses including business principles, the start of new businesses, new corporate finance, entrepreneurial law, technology and entrepreneurship.

Premier Li Keqiang used the word "maker" in the 2015 government work report. Prior to this, China started to talk about the entrepreneurship. However, entrepreneurial education in colleges and universities is still in its infancy. In particular, design-oriented colleges and universities, entrepreneurship curriculum system is not perfect. There is no full-time professional teacher. With limited resources, design students can't get the professional guidance or expansive guidance. Many venture projects come to a premature end. Therefore, they should strengthen the entrepreneurial knowledge of the students in the colleges of arts. In the design education, to reflect the concept of maker is very necessary.

The research of this project is to combine the spirit of "Maker" with the education of advertisement design. It should use new thinking and new method of "Maker concept" to cultivate students' innovative thinking, innovative spirit and innovative ability in the brand image planning and design specialty. Also, it should study "maker concept" in the design of teaching module. The teachers should use "Maker" activities to stimulate the interest and desire of the students. And then, design education would have the transformation fro $m$ the previous "learning fro $m$ the teachers" into "learning by themselves". The current design education of the colleges and universities ignores the personalized hands-on research ability and problem-solving ability. It urgently needs to be strengthened. Maker education also provides new solutions to solve the practical problems such as high scores and low abilities and rare innovative talents in current personnel training. And it provides new solutions for modern design education.

\section{THE EST ABLISHMENT OF INNOVATION MODULE OF BRAND IMAGE PLANNING COURSES}

The colleges and universities should summarize many years of practical experience in education and teaching. In particular, they should pay attention to the provincial project of "teaching methods and implementation strategies of fast 
design". The teachers should accumulate the experience of a number of creative projects. The colleges and universities should foster innovation talents in line with the needs of social and economic development. And it is a starting point. It should build complete curriculum module to reflect the concept of maker. And this curriculum module should be on the knowledge and skills. The purpose is to impart knowledge of maker education, improve entrepreneurial skills, cultivate entrepreneurial spirit, strengthen entrepreneurial awareness, encourage pioneering practices and cultivate various conditions or literacy for entrepreneurs. With careful discussion of the research group, the course modules include two major innovative modules: the Internet module and design education module.

\section{A. Internet Module}

With the Internet resources, the colleges and universities should introduce maker space model, establish online virtual community and offline physical space. With online virtual community, students can share the knowledge of advertising design. And it would achieve the sharing of resources. Students can gather together offline. Through the discussion on the knowledge of brand planning, students can work together to create results. And they could build entity studio with the thinking collision.

Maker space in campus can be good supplementary to the laboratory. There is certain management system in the campus laboratory, which is not as open as the maker space. And many projects are academic. The maker space is flexible. The maker students do their own favorite things with their interests completely. It aims at improving students' creative ability and operational ability. At present, all major colleges and universities have set up entrepreneurial incubation bases, which have laid solid foundation for the students' entrepreneurship and maker activities.

\section{B. Design Education Module}

1) Design Education Module of advertising specialty: In the structure of professional ability, the colleges and universities should pay attention to creative advertising, aesthetics and technical performance training. In the era of innovation times, the creativity should be the first. And aesthetic quality and technical performance are important parts to improve the creativity. Therefore, it is necessary to establish the correct guiding ideology embodying this training direction from the three modules of advertisement theory course, advertisement foundation course and professional course. That is to say, the core concept of curriculum teaching runs through innovative teaching, such as design aesthetics, writing and layout design, brand planning courses, etc. The colleges and universities should cultivate students' creative ability and improve their aesthetic and technical abilities.

2) Experiential module: Student should actively have the learning. And it is the core of experiential education. In the experiential teaching, students are the center of learning. Students are allowed to participate in or expose themselves to certain design scene. And the senses are used as media to experience, concern, learn and evaluate the design links personally. And then, the students would acquire relevant knowledge and skills. For example, the students could have experiential learning and sand table simulation.

3) Project module: The colleges and universities should develop maker education with the projects. With the innovation, the teachers would bring students to start their own business. The teachers would bring the students to start the entrepreneurship. The project teaching could take the tasks in continuous weeks or semester as the center. The students would complete the task of learning in the process of collaboration. Taking the entrepreneurship project of college students as an example, the students would find their own interested projects. Under the guidance of the research group, students could make the feasibility study, planning, formulation, implementation steps, academic value, economic value and laws and regulations of these projects. Students can complete entrepreneurial projects in scientific and efficient ways.

4) DIY module: In addition to educational philosophy, maker education has also been affected by DIY concept. People are familiar with DIY concept. Without the help of experts and professionals, the students could repair, rebuild, make or create the same thing by themselves. DIY concept emphasizes the cultivation of their operational ability. And the students should enjoy the achievements. In the maker movement, it has played significant impact. In fact, many makers embark on this path from being DIY enthusiasts.

Through the above innovation module set in the advertising design, the students should develop certain sense of innovation, innovative thinking, innovative ability and innovative personality. And it is the main goal of education theory and method. In practice, innovative education has different forms. However, the ultimate goal is to foster students' groundbreaking.

\section{THE DIFFICULTIES OF MAKER CONCEPT IN THE BRAND IMAGE PLANNING COURSES}

\section{A. The Key Point of Maker Concept in Brand Image Planning}

Compared with other majors, students in arts schools have some disadvantages in starting their own businesses, especially for the students of advertising design. They mainly focus on divergent thinking. And their logic is weak. However, the maker system requires close logical thinking skills. Many students only have entrepreneurial passion. They lack the entrepreneurial thinking and theory. And a lot of venture capital projects are over. In addition, the subjects such as economics and management are scarcer. And there is a certain degree of difficulty in interdisciplinary studies. Therefore, it is especially important to put targeted economic management and maker courses into the curriculum system of brand image planning. Through regular lectures and training provided by corporate executives, successful makers and professional legal advisers, students would have rich 
theoretical foundation in the process of starting business. And their projects will not come to a premature end.

The colleges and universities should formulate an entrepreneurial curricula program for the students of advertising design, which integrates with brand image design. And different origins and professional backgrounds, teachers should work together to guide students. It would achieve cross-class and cross-grade cooperation based on the projects. And regional colleges would share space resources with each other. They would also develop space-based alliance of regional maker education. The cooperation between universities and primary and secondary schools has strongly promoted the development of maker space. The sponsorship and support of enterprises have established a sound partnership between colleges and enterprises. It achieves mutual benefit and win-win situation. The participation of parents reflects the economic support. Also, it complements the shortage of teachers' resources.

Maker education emphasizes the deep participation in experiential education and inherits the idea of learning in practice. The frame of maker education is similar to the project learning, which centers on a specific learning task. The students would participate in a group to accomplish the task in the process of learning. And it could develop students' ability to solve problems. Maker education inherits the concept of innovation education to develop students' innovative thinking and innovative ability. Maker education also includes experiential education, project teaching methods and the innovative education. The students should be the center. It emphasizes and cultivates students' ability to learn independently. DIY concept is also integrated into the maker education. That is to say, the colleges and universities should cultivate the "craftsman spirit". The students would create and improve the ability independently.

\section{B. The Key Points of Maker Concept in Brand Image Planning}

There are also some difficulties in the process of learning maker education for students who study the brand image planning course. As the students of other majors, they lack social experience. And their full-fledged entrepreneurial enthusiasm would be hit and tested by the social reality. Especially, after the failure, if the students don't have good attitude. They are likely to be depressed. And it is difficult to cheer them up. Therefore, to have a healthy attitude is very important for the makers.

Students of advertisement design should learn the knowledge on art theory during the academic year. They have too many enterprising ideas. And they are boundlessly optimistic about starting the business. The theoretical knowledge is difficult to combine with the practice of entrepreneurship. The students lack real understanding of business prospects. The entrepreneurial ideas and concepts can't stand the test of reality and the market. In the early days of entrepreneurship, many college students could not insist on accumulating credit in the face of little capital and few tourists. They did not have the perseverance and psychological endurance of suffering from setbacks.

\section{THE MAIN POINTS AND INNOVATION}

\section{A. The Main Points}

Maker education is a phenomenon of educational innovation that has arisen in the education sector under the background of maker movement. The combination of maker idea and brand image planning inherits the project teaching method. It also realizes the student-centered teaching thought in practical learning. And it opens up the practice field of innovation and entrepreneurship education with the integration of information technology.

For the students of brand image planning, the innovative spirit emphasized by maker education and the ability to comprehensively use knowledge and skills to solve practical problems are necessary in the future. Moreover, among the maker projects, the application of emerging technologies is indispensable. Students have the opportunity to learn emerging technologies in the process of completing the course. It is also necessary reserve of knowledge in today's technologicalage.

Maker education is conducive to develop operational abilities of the students in brand image planning courses. And it could foster the culture of "paying attention to the skills and technology". Maker education advocates to make the operation independently. It encourages the innovation and development. Under the background of examinationoriented education and one-child society in China, there is the phenomenon of "focusing on the brain and the theory, ignoring the operation and the practice" for a long time. Therefore, it is necessary to promote maker education in China.

\section{B. The Innovation}

The student-centered teaching thought has gone throughout the combination of maker education and brand image planning. Compared with the traditional teachercentered teaching methods, maker education provides new teaching mode of advertisement design for modern toner education. This new model encourages students to develop their strengths. And the students would find ways to learn for themselves. Compared with the traditional model, maker education would respect individual differences.

Maker education provides the space for the students of brand image planning to have the interaction and cooperation. The teamwork is an important part of maker education. In addition to teachers, students could receive feedback from each other timely. Also, they could learn from each other during the cooperation process. In addition, the interactive process of completing the project would also be conducive to cultivate students' team spirit and cooperative ability. Also, it helps to enhance the cohesion of the class.

Information technology has provided an environment for maker education outside. And it has also promoted the communication of the students of advertising design internally. With the help of information technology, students can gain more resources through the Internet platform. And the students could have the communication in real time without being limited to space and time. The development of 
maker education will greatly promote the innovation and development of educational informatization in China.

It is the inventiveness. The projects of maker and brand image planning aim at stimu lating the innovative spirit of the students. And the students should break the thinking. The teachers should always keep an open mind in guiding maker projects and encourage the students to make innovation. Also, the teachers should learn with the students.

\section{BASIC IDEAS AND METHODS}

\section{A. To Clarify the Goals of the Project}

A good project of maker and brand image planning should be able to maximize the enthusiasm of students. And it should link with the practice. The goal of the project can be summarized into two points. First, the students of advertising design should master related knowledge and skills of the business or entrepreneurship. Second, the students of advertising design should have the practical ability to turn a creative thing into an entity. And everyone could see it. The students would become real makers.

\section{B. Specific and Composite Structure of the Project}

A project of good maker and brand image planning should encourage students to work together with the knowledge of multiple disciplines. When designing a project, teachers should consider the existing knowledge of students and their respective expertise fields. It would mobilize the potential of students. The students can use existing knowledge to solve the problem to the maximum extent. It includes four major structures of pre-employ ment skills areas, business areas, business management, and professional fields.

\section{Scientific Content of the Education Project}

The project content of maker and brand image planning belongs to the "radiation" or "proliferation". It should focus on the training and upgrading of entrepreneurship and innovation ability. It reflects the close combination of entrepreneurship and various subject areas, such as art entrepreneurship, pre-entrepreneurship, venture area, corporate image, and regional knowledge and skills of business management. Pre-business regional courses mainly help the students understand what the business is, what knowledge and skills are needed, and why the students should start business. It is the basic curriculum to encourage students to start their own business. The entrepreneurial regional curriculum involves the design of business plans, business finance, the development of business plan, etc. The regional courses of business management include the company management, such as market issues, financial issues, and the decision-making of company, management innovation, team leaders, business-related laws and other aspects of knowledge.

\section{The Implementing Agencies}

In the major art colleges and universities in China, there are no full-time teachers in entrepreneurship education. Therefore, they use the teachers of current colleges and universities to have the courses. Also, the colleges and universities would take expert speeches and successful sharing experiences of maker. Compared with other implementing agencies of design institutes, the teaching teachers could be local government officials, entrepreneurs, and successful maker. Also, it would be conducive to the production, learning and education.

\section{E. Financial Funds}

The school is a non-profit organization. Under the limited resources, the students could apply for small-scale loans. One of the major policies to encourage the entrepreneurship is to provide small-scale loans. For self-employed businesses, in addition to the supportive policies of the state, there are also some relevant preferential policies to encourage college graduates to start their own businesses.

To participate in the advertising entrepreneurial competitions is a challenge for college students. The participation is a process of learning and harvest. Also, it is an opportunity to receive bonuses. Generally, the training fund of entrepreneurship is very rich. In the competition, the first player would often get entrepreneurship training fund of 100000 yuan. Many college students will participate in venture competition. And it is a chance to challenge themselves. It is also a platform to have the entrepreneurship combat.

\section{CONCLUSION}

At present, colleges and universities should cultivate creative and applied talents in China. It is particularly important for students to have innovative thinking and practical ability. Teachers should teach relevant professional knowledge. They should also train students to set up correct moral values. The students can design products. At the same time, the students could feel the psychological feelings of consumers. The work would fit the needs of the audience. Teachers should teach the knowledge on maker concept and brand image design. At the same time, students would complete the home work. Als o, it cultivates new learning and innovative thinking mode in this process. It is basic literacy of advertising designer. Through the creation, the students could have the communication. Through the training of innovation and entrepreneurial brand image planning and the needs of social audiences, they should establish a balance. And the colleges and universities want to develop the continuous growth of advertising design talent in the continuous exploration of the design origin. The brand image planning and design will continue to be improved.

\section{REFERENCES}

[1] Li Liangjun, Huang Zhaohui. Fast design and expression [M]. Wuhan: Hubei Fine Arts Publishing House, 2009: 7.

[2] Zhong Baichang, Zhang Lifang. The role of "transformation equations" in American STEM education reform and its enlightenment [J]. ChinaEducational Technology, 2014, (4): 18-24.

[3] Wu Junjie. Maker movement and STEM education - An interview with "Maker Godfather" Mitch Altman [J]. Information Technology in Primary and Secondary Education, 2013, (12): 39-42. 
[4] Zhang Zhuyun. Entrepreneurship education in the United States [M]. Beihang University, 2003 (3).

[5] Wu Zhi, Hu Bingyu. Comparison of Sino-American business model and enlightenment [J]. Journal of Educational Development. 2010 (7).

[6] Zhang Fan, Zhang Wei. Entrepreneurship education in American universities and its enlightenment [J]. Chinese Talents, 2003, (8): 710.

[7] Wu Yongqiang, Wang Peijun, Zhou Yu. On the optimization of ent repreneurship education in colleges and universities [J]. Journal of Southwest Agricultural University: Social Science Edition, 2011 (11). 